\title{
Hospitalitas Kristen \\ Mewujudkan Pemuda Dalam Melayani Jemaat
}

\author{
Yelmi Nino \\ INSTITUT AGAMA KRISTEN NEGERI TORAJA \\ yelminino270201@gmail.com
}

Abstrak : Worship is a process of getting closer to God through praise based on expressions of gratitude for God's love and goodness. Considering our lives, especially our youth today, many do not understand the meaning of worship and it is easy to fall or commit sins because it is considered a period of searching for identity. Therefore, youth are required to involve themselves in ministry, calling, or join fellowships and be guided by pastors or councils and congregations so that youth grow and develop according to their Christian character. Every believer must understand the basics of believer's worship, namely the blood of Jesus who was shed for us human beings who also took our place on the cross and gave himself for us.

Abstrak : Ibadah merupakan proses untuk mendekatkan diri kepada Tuhan melalui puji-pujian yang dilandasi dengan ungkapan syukur oleh karena kasih dan kebaikan Tuhan. Mengingat kehidupan kita khususnya kita sebagai pemudah saat ini, banyak yang kurang memahami tentang makna beribadah dan mudah untuk jatuh atau melakukan dosa karena di anggap sebagai masa pencarian jati diri. Oleh karena itu pemuda di haruskan untuk melibatkan diri dalam pelayanan, panggilan, maupun mengikuti persekutuan-persekutuan dan dibimbing oleh pendeta atau majelis serta jemaat agar pemuda tumbuh dan berkembang sesuai dengan karakter kristiani. Setiap orang percaya harus mengerti dasar-dasar ibadah orang percaya yaitu darah Yesus yang telah dicurahkan bagi kita umat manusia yang juga telah menggantikan kita di kayu salib serta menyerahkan dirinya untuk kita.

Kata Kunci: Pemuda yang melibatkan diri dalam pelayanan 


\section{PENDAHULUAN}

Kehidupan dunia remaja pada saat ini membentuk mereka menjadi keras kepala, suka memberontak terhadap orang tua, tidak mau diatur oleh orang lain, bahkan tidak memperdulikan agama. Mereka suka hidup dalam kebebasan, artinya bebas dalam kehendak dan berbuat sesuai dengan keinginan hati. Dunia ini mempengaruhi bahkan mengusai pikiran mereka untuk selalu berfikir hari ini saja, tidak memikirkan masa depan. Oleh sebab itu, pemuda seringkali banyak melakukan perbuatan dosa. Dosa membuat mereka gagal, frustasi dan menjerat mereka kepada kehidupan seperti: Free seks, narkoba, serta kenakalan remaja (Pencurian, perkelahian dan minuman keras). Untuk mengubah atau menjembatani pemuda adalah iman. Imanlah satusatunya jembatan untuk mencapai semua harapan dan impian menjadi dunia nyata. Iman dapat menerobos masuk kedalam tempat yang gelap dan mengubahnya menjadi terang. Memang berat bagi remaja untuk meninggalkan kesenangan duniawi dan mencari kesenangan Tuhan, namun kemuliaan akan diperoleh di kemudian hari. Dunia kasih adalah dimana Allah mengasihi manusia dan manusia mengasihi Allah dengan cara kita melayani-Nya.

Dalam meningkatkan pertumbuhan kerohanian pemuda untuk pengenalan Yesus Kristus, badan pengurus jemaat harus berperan aktif untuk pemuda agar mereka tidak terbawa oleh pergaulan dan arus dunia ini. Selain itu, badan pengurus jemaat harus menjalankan perannya sebagai pelayan Tuhan dalam meningkatkan pertumbuhan kerohanian pemuda. Pelayanan kepada pemuda untuk meningkatkan kerohanian mereka yang dilakukan oleh badan pengurus jemaat kepada pemuda sangatlah penting untuk dilakukan karena pemuda merupakan bagian yang terpenting di dalam gereja, dan masa muda adalah masa transisi di mana kaum muda sangat membutuhkan bimbingan. Salah satu indikator yang di gunakan dalam Melihat keberhasilan sebuah gereja adalah jumlah persentase jemaat yang Melayani tidak terkecuali para generasi Muda. 7 dari 10 generasi Muda Kristen di jemaat yang rutin terlibat dalam pelayanan, rata-rata itu sebagai pengurus, persentase yang Melayani di gereja itu rata-rata lebih banyak perempuan dari pada laki-laki. Mereka yang terlibat dalam pelayanan lebih berinteraksi tentang pengenalan akan Yesus. Ikut serta dalam pelayanan juga berdampak positif bagi pemuda dalam kedisiplinan. 


\section{TUJUAN DAN MANFAAT}

a. Tujuan penulisan

Peran pemuda dalam melibatkan diri dalam melayani jemaat untuk meningkatkan pertumbuhan kerohanian pemuda Gereja Kristen.

b. Manfaat penulisan

Manfaat yang diperoleh dari hasil penelitian ini ialah dapat membentuk karakter kaum muda dan menjadikan mereka sebagai murid Kristus yang dewasa dalam iman serta mengaplikasikan setiap ajaran tentang firman Allah yang telah didapatkan dalam panggilan dan kesetiaan pemuda dalam beribadah.

\section{PEMBAHASAN}

Melayani Tuhan adalah dunianya pemuda, karena disinilah akan mendapat berbagai pengalaman organisasi, tetapi juga pengalaman iman bagi Tuhan. Tuhan telah mempersiapkan pemuda untuk menjadi alat dalam tangan Tuhan untuk melayani sesama pemuda dan juga kepada jemaat. Dalam pelayanan, pemuda akan lebih mengenal dirinya sendiri. Hubungan yang dekat dengan Tuhan memberikan sukacita dan damai sejahtera yang luar biasa, yang tidak bisa diukur dengan uang dan materi. Remaja adalah tulang punggung gereja dan jemaat karena memiliki potensi-potensi yang luar biasa dan harus dijaga yang telah diberikan dan dipercayakan kepadanya. Jika talenta itu dikembangkan maka harapan dan masa depan yang gemilang akan menjadi miliknya, serta gereja, masyarakat dan Negara akan semakin bersinar. Empat potensi yang dimiliki oleh seorang pemuda Kristen yaitu:

1) Memiliki semangat (Roh/Spirit) yang menyala-nyala

Semangat dalam melayani Tuhan seperti nyala api Tuhan yang tidak dapat dihalangi oleh apapun. Tantangan yang sili berganti baik dalam diri maupun dari luar, tidak membuat mereka lelah dan putus asa dalam melayani. Gereja dan jemaat akan bangkit ketika pemuda ikut serta dalam pelayanan. 
2) Memiliki kekuatan yang luar biasa

Kekuatan ini digambarkan seperti dua sayap rajawali (Firman Allah \& Roh Kudus) yang dapat terbang tinggi serta memiliki daya yang bisa mempengaruhi anak-anak Tuhan. Kekuatan inilah yang membuat mereka tetap teguh dan kokoh dalam mengahadapi pengaruh dunia (Keinginan daging, keinginan mata dan keinginan hidup). Kekuatan ini merupakan talenta-talenta atau karunia Roh yang diberikan untuk melayani Tuhan.

3) Hidup dalam kesucian

Hidup dalam kesucian atau kekudusan berarti menjauh atau terpisah dari dosa, godaan dunia, dan iblis. Hidup dalam kesucian berarti hidup taat kepada firman Allah dan hidup dalam hadirat Allah.

4) Memiliki perhiasan rohani

Pakaian putih lebih menekankan perbuatan yang benar, sedangkan perhiasan rohani lebih ditegaskan tentang sifat kelema-lembutan.

Pemuda dan masa depan, ibarat "manusia dan udara", adalah dua hal yang tidak dapat dipisahkan karena telah menjadi kodrat bagi pemuda sendiri, yang sering disebut-sebut sebagai masa depan, tunas bangsa, dan pelanjut generasi, sejarah telah membuktikan bahwa pemuda turut berdiri dalam rangkaian upaya pembangunan bangsa. Bahkan ketika kita berbicara tentang sejarah bangsa Indonesia, pembicaraan tersebut tidak bisa terlepas dari konteks kepemudaan. Pemuda Kristen harus berani menempatkan kesejahteran, keadilan, kebenaran, keutuhan ciptaan dan demokrasi di Indonesia yang berdasarkan dengan kasih. Dengan kata lain pemuda Kristen harus menjadi pelopor terwujudnya "shalom Allah" di muka bumi ini. Hal ini akan menunjukkan bagaimana pemuda Kristen merelevansikan imannya di tengah-tengah kehidupan dunia. Oleh karena itu, konsep persekutuan dan nasionalisme merupakan dua hal yang sangat berkaitan dan dua hal ini sepatutnya di miliki oleh pribadi pemuda Kristen. Pemuda Kristen di tuntut meningkatkan ketekunan dalam kejujuran, mengasag setiap potensi yang dimiliki dan menyalurkan kreativitas yang mengarah pada pembangunan bangsa Indonesia. Sebagian bagian dari anggota tubuh kristus, generasi muda di gereja seharusnya ikut berperan aktif bekerja melayani Tuhan. 
Mereka akan menjadi anggota gereja yang baik dan peran di masyarakat sebagai saksi kristus. Perkembangan era digital yang semakin pesat saat ini telah mempengaruhi kehidupan rohani manusia. Di tengah kecanggihan cara berkomunikasi yang mempermudah kehidupan manusia dan meningkatnya kesejahteraan bangsa Indonesia. Idealnya jemaat Tuhan mengucap syukur seperti tertulis dalam Efesus 5:20. Ucaplah syukur senantiasa atas segala sesuatu dalam nama Tuhan kita Yesus Kristus kepada Allah dan Bapa kita. Namun, dalam kenyaatannya kehidupan rohani jemaar Tuhan di Indonesia khususnya para pemuda di kota. Dimana maraknya kasus kenakalan pemuda seperti penyalagunaan narkoba, kehamilan di luar nikah, tawuran antar pemuda, mabuk-mabukan adalah beberapa contoh persoalan sosial pemuda yang dihadapi bangsa Indonesia saat ini. Pemuda Kristen tak terkecuali juga menjadi penyumbang dari kasus persoalan tersebut. Kehidupan rohani pemuda tersebut harus diubah dratis melalui sebuah tindakan nyata dari semua pihak, tidak hanya oleh para pemuda saja namun perlu upaya yang berssama orang tidak hanya oleh para pemuda saja namun perlu upaya bersama orang tua dan gereja dan seluruh pemimpin bangsa. Apabila pemuda sudah tidak memiliki motivasi hidup yang kuat maka dapat dibayangkan akan menjadi apa jemaat Tuhan di masa depan.

Firman Tuhan pengkhotbah 12:1 secara jelas berkata kepada para pemuda bahwa di dalam masa mudanya seharusnya mengingat penciptannya sebelum tiba hari-hari yang malang dan mendekat tahuntahun yang tak ada kesenangan atau masa -masa kesusahan. Mengingat Tuhan berarti menempatkan Tuhan pencipta dalam setiap motivasi dan langkag kehidupanya. Dalam kenyataannya pada orang tua, gereja dan pemerintah saat ini belum mampu memahami persoalan kehidupan rohani pemuda yang merosot ini dan membiarkan pemuda berjalan sendiri tanpa pemimpin dalam pencarian identitas dan destini mereka. Hal ini merupakan suatu masalah yang perlu dipecahkan dan diselesaikan supaya pemuda bertumbuh rohaninya dan dapat menjadi generasi penerus hereja serta membawa gereja ke kehidupan yang damai sejahtera dimasa depan. Melihat hal tersebut, meningkat kehidupan rohani pemuda melalui pertumbuhan rohani menjadi suatu prioritas agar pemuda dapat berdiri teguh di atas kebenaran Firman Tuhan serta menyadari tugas dan tanggung jawabnya 
sebagai generasi penerus yang menjadi harapan gereja, bangsa, dan negara.

Dengan keadaan seperti itu kaum muda membutuhkan pelayan Tuhan yang benar- benar ingin meningkatkan kerohanian pemuda untuk pembentukan kerohanian mereka, karena generasi muda merupakan pemegang kendali arah pelayanan ke depan. Ketika generasi muda dilayani dengan baik dan kerohanian mereka mulai bertumbuh dengan sebaik mungkin, maka gereja akan bisa maju dan berkembang dan membawa perubahan bagi jemaat yang lain. Ketika pengurus jemaat melalaikan pelayanan kepada kaum muda, maka sudah dipastikan bahwa keadaan pelayanan gereja akan mengalami kemunduran yang sangat mempengaruhi rohani jemaat khususnya bagi pemuda gereja. Dengan demikian, bahwa setiap pelayan Tuhan dalam gereja harus memperhatikan dan mempedulikan pelayanan kepada pemuda, tidak dipungkiri lagi sesuai dengan fakta dan berdasarkan kesaksian dari pemuda di gereja setempat bahwa badan pengurus jemaat kurang menjalankan perannya sebagai pelayan Tuhan, kurang memberi perhatian terhadap kaum muda sehingga kerohanian mereka tidak mengalami pertumbuhan dan mengalami kemunduran. Dapat dikatakan bahwa keterlibatan kaum mudah dalam pelayanan di gereja berpengaruh sangat signifikan terhadap kehidupan spiritualitas didik oleh karena itu perlu adanya usaha untuk mempertahankan dan meningkatkan persentase kehidupan keterlibatan tersebut. Lalu hal-hal apa saja yang dapat membuat kaum muda ikut dalam pelayanan di gereja jika dikelompokkan terdapat dua faktor utama yang secara cukup signifikan dapat membuat kaum muda yang rutin ke gereja untuk ikut pelayanan yaitu gereja dan orang tua.

Gereja adalah pihak yang paling berpengaruh mempengaruhi pemuda untuk ikut tidaknya dalam pelayanan kaum muda yang merasa bahwa gereja mendorong untuk terlibat pelayanan akan cenderung lebih mungkin untuk terlibat pelayanan. Selain dorongan secara aktif yang diberikan oleh Gereja ada juga mereka yang tergerak karena mendapatkan manfaat dari gereja itu sendiri. Mereka yang menemukan teman sejati atau komunitas akan cenderung lebih mungkin untuk ikut melayani. Sedangkan mereka yang mendapat manfaat dari program-program Gereja, baik itu khotbah hari Minggu, Bible study seminar maupun diskusi akan lebih mungkin untuk terlibat dalam pelayanan dibandingkan dengan yang tidak mendapat apa-apa. 
Kemudian Orang tua sebagai lingkungan terkecil dan roli model juga cukup berpengaruh bagi generasi muda untuk aktif dalam pelayanan di gereja. Mereka yang orang tuanya sangat rajin beribadah akan lebih mungkin untuk terlibat melayani, sedangkan mereka yang sangat aktif dalam pelayanan cenderung lebih mungkin untuk aktif melayani selain itu juga mereka yang spiritualitasnya dibimbing dengan baik oleh orang tuanya akan cenderung lebih mungkin untuk ikut pelayanan.

Untuk dapat melibatkan semakin banyak pemuda dalam pelayanan, maka dibutuhkan kepanitiaan atau kepengurusan yang cukup untuk menampung dan sesuai dengan kapabilitas dan minat dari kaum muda yang ada di gereja. Kepanitiaan dalam berbagai program kamu dapat menarik minat anak muda, karena dalam sebuah acara kan pasti dibutuhkan berbagai macam talenta seperti kreativitas acara dekorasi musik dan lain sebagainya. Mereka bisa mengaktualisasikan diri mereka dan terutama tentang mereka dalam kepanitiaan tersebut. Selain itu juga perlu membuka peluang bagi kaum muda untuk melayani berbagai program pelayanan mingguan agar mereka dapat menyalurkan talenta dan sekaligus menghargai keberadaan mereka dalam gereja titik penting untuk membuat mereka merasa dihargai dan dibutuhkan dalam pelayanan di gereja tentu saja membuat mereka merasa dibutuhkan bukan dalam artian pelayanan bertanggung jawab pada generasi muda tetapi lebih menganggap kesetaraan atas keberadaan mereka di gereja bukan sebagai Jemaat. Tentu saja jika kaum muda sering terlibat dalam pelayanan Semakin banyak teman dan komunikasi dalam gereja yang mereka miliki hal ini membuat mereka memiliki komunitas yang baik dan juga mereka semakin aktif melayani di gereja. 


\section{KESIMPULAN}

Masa depan remaja dikatakan sebagai masa-masa emas dan akan diisi dengan berbagai kegiatan untuk menyambut masa depannya. Jika mereka tidak melibatkan pemuda dimasa emas ini, gereja akan kehilangan kesempatan untuk membina remaja menjadi pemimpin gereja masa depan. Jika mereka dapat dibina dengan baik atau melibatkannya dalam pelayanan maka akan menjadi pemuda-pemuda yang berpotensi yang dapat memberi pengaruh kepada gereja, terutama menjadi teladan bagi pemudapemuda lain. Pemuda sebenarnya memiliki vitalitas untuk bertumbuh dan berkembang baik secara fisik, intelektual, sosial, emosional dan spiritual sehingga tugas pelayanan gereja yang dibutuhkan adalah mendampingi dan menuntun generasi muda dan melibatkan dalam pelayanan serta memahami panggilanya di tengah-tengah arus zaman. Menjadi Agen penggerak Tubuh Kristus yang bertumbuh. Pemuda yang telah di bina dengan baik akan menghasilkan pemuda dengan iman yang dewasa. Pemuda yang dewasa secara rohani bukan saja bisa bertumbuh melainkan libatkan dalam tugas pelayanan gereja, tetapi juga dapat menjadi agen penggerak bagi pertumbuhan iman tubuh kristus secara keseluruhan. Penulis sangat membutuhkan kritikan serta saran untuk penulisan penelitian yang lebih baik dan lebih bermanfaat. 


\section{REFERENSI}

Gainau, Markus S. Pendidikan Agama Kristen (PAK) Remaja, Yogyakarta: PT Kanisius, 2021

Isir, Kornelius Paulus, Pemuda Pembangun Tubuh Kristus, Yogyakarta:PT Kanisius, 2020

Hutayan, Benny, Peran Kepemimpinan spiritual dan Media Sosial Pada Rohani Pemuda, Yogyakarta : CV Budi Utama, 2019

Silalahi, Tomson Sabungan, Pemuda Milenial, Jawa Barat : CV Jejak,2019

Sukarman, Timotius, Gereja yang Bertumbuh \& Berkembang, Yogyakata : ANDI, 2012 